\title{
Faktor-Faktor yang Mempengaruhi Efektivitas dan Efisiensi Sumber Daya Manusia di Klappertaart Huize Cafe and Resto Bogor
}

\author{
Ammar Abdulbaqi, Agus Sudono, Oman Sukirman \\ Manajemen Industri Katering, Fakultas Pendidikan Ilmu Pengetahuan Sosial, Universitas \\ Pendidikan Indonesia, Jl. Dr. Setiabudhi No. 229, Bandung 40154, Indonesia
}

*Koresponding Penulis. E-mail : ammarabdulbaqi@student.upi.edu (Ammar Abdulbaqi)

\begin{abstract}
Abstrak
Penelitian dilakukan untuk mencari faktor- faktor yang mempengaruhi efektivitas dan efisiensi SDM di perusahaan Klappertaart Huize Café \& Resto (KHCR) Bogor. Metode yang digunakan adalah metode deskripsi dan explanasi (explanatory). Responden dibedakan antara unsur karyawan dan pimpinan perusahaan. Diskusi lebih lanjut dan atau wawancara dilakukan untuk memperdalam informasi yang diperoleh. Dalam penelitian ini teridentifikasi faktor-faktor yang mempengaruhi efektivitas dan efisiensi SDM di KHCR Bogor ialah : (1) ragam media pengumuman rekrutmen karyawan; (2) masa orientasi karyawan baru; (3) jumlah dan frekuensi pelatihan karyawan; (4) mekanisme reward and punishment; (5) kegiatan sosial bersama karyawan; (6) ragam program K3; (7) semangat dan motivasi karyawan; (8) tingkat kepuasan karyawan terhadap pekerjaan; (9) penghematan sumberdaya; (10) kepatuhan terhadap SOP; dan (11) tantangan dari pesaing.
\end{abstract}

Kata Kunci: Pengelolaan SDM Restoran; Tingkat Kepuasan Karyawan; Resto dan Cafe

\section{Pendahuluan}

Jumlah wisatawan yang cukup besar di kota Bogor membutuhkan dukungan usaha kuliner yang memadai. Iklim usaha yang baik juga sangat diperlukan untuk mendukung usaha kuliner. Peraturan di tingkat pemerintah pusat maupun pemerintah daerah sangat membantu berjalannya industri pariwisata dan kuliner. Beberapa peraturan terkait misalnya : (1) Peraturan Pemerintah Republik Indonesia. Nomor 184 tahun 1961, tentang pendirian perusahaan negara industri makanan dan minuman, (2) Peraturan Menteri Pariwisata Republik Indonesia Nomor 28 tahun 2015, tentang Standar Usaha Penjualan Makanan, (3) Peraturan Daerah (Perda) tentang rencana induk pembentukan kepariwisataan daerah tahun 2016-2025.

Salah satu wisata kuliner yang menyajikan kuliner khas adalah
Klappertaart Huize Cafe and Resto (KHCR) yang beralamat di Jalan Pangrango, Bogor. KHCR adalah salah satu bidang yang bergerak dalam penyediaan jasa konsumsi / jasa boga dengan tiga produk utama, yaitu: Klappertaart, Makaroni Skotel, dan Pastel tutup. KHCR telah berdiri sejak tahun 2008 dan memiliki pengalaman dalam penyediaan snack, mealbox, coffee break dan buffet.

Beberapa permasalahan yang dihadapi KHCR dalam pengelolaan Sumber Daya Manusia (SDM) yaitu: kedisiplinan, penempatan SDM, kepatuhan terhadap SOP, serta efektivitas dan efisiensi pengelolaan SDM.

Penelitian dimaksudkan untuk menemukan faktor - faktor yang mempengaruhi efektivitas dan efisiensi pengelolaan SDM.

Manajemen SDM adalah serangkaian proses untuk dapat menangani 
permasalahan- permasalahan yang terjadi dalam lingkup karyawan, buruh, manajer, pegawai, manajer dan tenaga kerja yang lainnya supaya mampu menunjang kegiatan perusahaan untuk dapat mencapai tujuan perusahaan yang telah ditentukan.

Seperti halnya manajemen umum, fungsi manajemen operasi SDM juga meliputi fungsi manajerial yaitu : perencanaan (planning), pengorganisasi (organizing), pengarahan (directing) dan pengendalian.

Dalam pengelolaan SDM, diperlukan fungsi fungsi: pengadaan, pengembangan, kompensasi, pengintegrasian, dan pemeliharaan (Hasibuan, 2014).

Fungsi pengelolaan SDM tersebut harus berjalan dengan efektif dan efisien. Dalam pengertian efektif mengandung makna: (1). tercapai tujuan/target pada batas waktu yang ditentukan, (2) terpenuhi jumlah maupun mutu hasil pekerjaan pada waktu yang ditentukan, (3) segala sesuatu untuk memperoleh waktu yang diinginkan, (4) tercapai tujuan tanpa memperhatikan biaya yang dikeluarkan, dan (5) mengerjakan sesuatu yang benar (doing the right thing).

Dalam pengertian efisiensi terkandung makna :

a. Mencapai tujuan/target dengan biaya yang sama tapi hasil yang diperoleh lebih besar,

b. Upaya untuk mengurangi sumber daya agar tetap menghasilkan tujuan/target,

c. Menghasilkan sesuatu tanpa memboroskan sumber daya, waktu/energi,

d. Upaya untuk menghemat atau mengorbankan modal kerja untuk mencapai tujuan/target, dan

e. Mengerjakan sesuatu/hal dengan cara yang benar (doing the thing right). Pandangan tersebut dirangkum dari pendapat para ahli seperti yang dikutip Iswanto (2014) dan Harianja (2002).

\section{Metode Penelitian}

Penelitian Metode penelitian ini berupa metode penelitian deskriptif dan eksplanasi (explanatory). Metode deskriptif pada penelitian ini berarti menggambarkan secara rinci keaadan dan kondisi perusahaan, berdasarkan data yang diperoleh dari wawancara, pustaka dan survei lapangan.

Metode penelitian eksplanasi pada penelitian ini berarti menjelaskan hubungan antara data yang diperoleh dari sampel dan melakukan generalisasi berdasarkan data sampel dari populasi yang diperoleh. Perolehan data dilakukan dengan menyebarkan kuesioner pada sampel dalam populasi.

Kuesioner dibedakan antara responden karyawan dan pimpinan perusahaan. Jawaban responden diverifikasi dan dilakukan diskusi mendalam untuk menggali data tambahan. Wawancara tertulis dengan pimpinan tertinggi juga dilakukan dalam bentuk pertanyaan terbuka.

\section{Hasil Penelitian dan Pembahasan}

Penelitian dilakukan dengan menyebarkan kuesioner kepada responden dengan kelompok usia seperti pada Gambar 1.

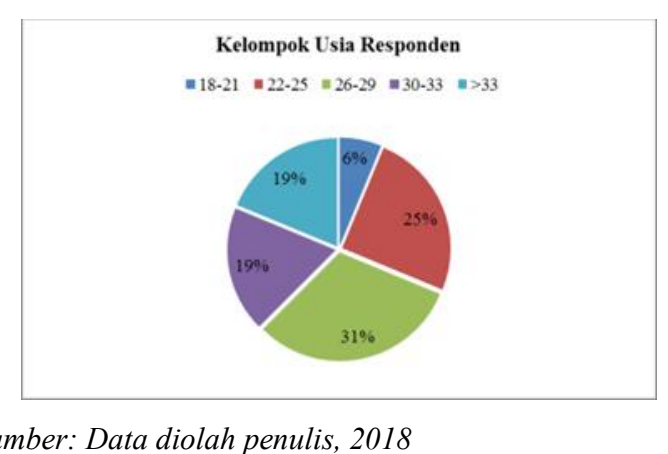

Gambar 1. Kelompok Usia Responden

Efisiensi dan efektivitas sangat ditentukan oleh faktor karyawan sebagai sumber daya manusia yang meliputi: (1) penerimaan pegawai, (2) masa orientasi pegawai, (3) pelatihan ketrampilan pegawai, (4) sistem reward dan punishment, (5) pembinaan kepegawaian, (6) program kesehatan, keselamatan, keamanan karyawan (K3), (7) motivasi, dan (8) tingkat kepuasan karyawan.

Ragam pengumuman rekruitmen 
diumumkan melalui media : (1) Internet/media sosial, (2) Koran/media massa, (3) Papan pengumuman, dan (4) Mulut ke mulut (Mouth to Mouth). Empat sarana itulah yang disiapkan dan digunakan oleh manajemen untuk pengumuman rekruitmen pegawai. Namun berdasarkan hasil kuesioner dengan karyawan, 75\% karyawan mendapatkan informasi tentang rekruitmen karyawan melalui media massa. Sebesar 8,3\% melalui media sosial, 8,3\% melalui papan pengumuman, dan $8,3 \%$ melalui mulut ke mulut.

Sebagian besar pegawai (75\%) memanfaatkan media massa sebagai pengumuman rekrutmen pegawai. Sarana pengumuman ini sebenarnya membutuhkan biaya yang cukup besar.

Efisiensi sebenarnya dapat dilakukan jika sarana pengumuman diahlikan ke media sosial, misalnya situs/laman, Facebook, Twitter, Instagram, dan lain sebagainya. Wadah komunikasi media sosial elektronik tersebut selain lebih efisien, juga lebih efektif untuk menjangkau calon pegawai yang lebih luas. Meskipun demikian, sarana lain seperti papan penguman dan selebaran masih dapat digunakan dalam jumlah yang terbatas. Sedangkan informasi dari mulut ke mulut akan muncul dengan sendirinya melalui media tersebut.

Masa orientasi pegawai dimaksudkan sebagai uji coba penempatan pegawai pada suatu penugasan yang sesuai dengan bakat, ketrampilan, dan pengalaman karyawan magang. Berdasarkan survey terhadap karyawan selama masa orientasi di Klappertaart, sebanyak $8,3 \%$ menjawab pada skala 10 (sangat puas sekali), sedangkan $8,3 \%$ menjawab pada skala 9 (sangat puas), 41,7\% menjawab pada skala 8 (puas), 33,3\% menjawab pada skala 7 (agak puas), 8,3\% menjawab pada skala 6 (sedang mendekati puas), dan 8,3\% menjawab pada skala 3 (tidak puas).

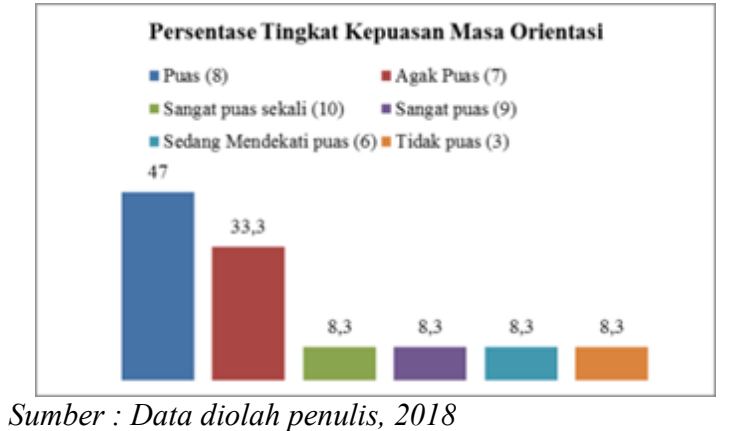

Gambar 2. Persentasi Tingkat Kepuasan Karyawan Selama Masa Orientasi di PT. KHRC

Jika dilihat pada Gambar 2, sebanyak $88.6 \%$ karyawan menyatakan sangat puas (9), puas (8) dan agak puas (7) terhadap pekerjaan selama masa orientasi. Kuesioner terhadap supervisor menunjukkan bahwa penilaian supervisor terhadap tingkat kepuasan pekerjaan karyawan magang rata rata pada skala 7.7. Hal ini menunjukkan bahwa supervisor belum puas terhadap kinerja karyawan selama magang.

Efektivitas SDM sangat dipengaruhi oleh kepuasan karyawan. Karyawan yang merasa puas, akan bekerja lebih efektif dan perusahaan mendapat keuntungan dan kepuasan dari hasil kerjanya. Adanya data pada kuesioner karyawan yang menyatakan karyawan tidak puas (3) sebesar 8.3\% hendaknya mendapat perhatian ekstra dari manajemen.

Pelatihan ketrampilan pegawai adalah upaya terus menerus untuk meningkatkan kemampuan, ketrampilan, dan pengetahuan karyawan. Pelatihan juga bisa menjadi media refreshing atau penyegaran bagi karyawan untuk meningkatkan kinerja.

Dari responden karyawan didapatkan sebanyak 91,7\% menjawab bahwa telah dilakukan Pelatihan Ketrampilan Pegawai oleh perusahaan, sedangkan $8,3 \%$ menjawab bahwa tidak ada Pelatihan Ketrampilan Pegawai. Hal ini dapat terjadi karena pegawai yang menjawab tidak ada pelatihan adalah karyawan baru yang belum masuk periode pelatihan reguler oleh perusahaan.

Jenis pelatihan yang saat ini berlangsung dan rutin dilakukan oleh KHCR 
adalah Tes Produk. Pelatihan ini meliputi prosedur melakukan tes produk dan uji coba produk baru atau tes untuk meningkatkan atau mempertahankan mutu produk yang sudah ada. Salah satu bentuk tes produk misalnya karyawan menciptakan produk baru dan perusahaan akan melakukan serangkaian tes meliputi : tes bentuk, rasa, dan aroma.

Pelatihan lainnya adalah Standard Operating Procedure (SOP) training yang dilakukan oleh manajemen untuk tahap awal suatu kegiatan atau perkembangan / perbaikan SOP.

Frekuensi pelatihan di Klappertaart berdasarkan kuesioner berkisar antara 2 hingga 3 kali per bulan. Frekuensi pelatihan tersebut dapat saja dilakukan lebih sering jika perusahaan ingin mengembangkan produk baru.

Pelatihan ketrampilan karyawan ini sangat membantu meningkatkan efisiensi dan efektivitas SDM karena karyawan yang lebih trampil akan bekerja lebih efektif dan tidak akan memboroskan sumber daya sehingga menjadi lebih efisien.

Reward adalah penghargaan bagi karyawan yang berprestasi, sedangkan punishment adalah hukuman bagi karyawan yang melakukan kelalaian atau tidak dapat meningkatkan prestasi. Dari hasil kuesioner baik untuk karyawan maupun supervisor, reward telah diberikan oleh KHCR tetapi punishment yang diberlakukan hanya dalam bentuk tidak memperoleh reward.

Dalam sistem reward (penghargaan) dan punishment (hukuman) di KHCR, sebanyak $83,3 \%$ responden menjawab bahwa adanya reward dan punishment, sedangkan $16,7 \%$ responden menjawab bahwa tidak adanya reward dan punishment.

Adanya karyawan yang menyebutkan bahwa tidak adanya reward dan punishment $(16.7 \%)$ setelah diverifikasi adalah karyawan yang belum pernah menerima reward. Reward yang diberikan oleh perusahaan KHCR berbentuk sertifikat, piagam, uang, certificate of the best employee, promosi / kenaikkan jabatan dan hadiah lainnya.

Pemberian reward dan punishment berdasarkan keterangan yang diperoleh dapat meningkatkan efektivitas dan efisiensi SDM. Karyawan yang mendapatkan reward merasa dihargai, mendapatkan apresiasi, menjadi teladan karyawan lain, menimbulkan rasa bangga, ingin membantu yang lain sehingga bekerja akan lebih efektif.

Upaya untuk merekatkan hubungan antar karyawan salah satunya adalah acara rutin bersama. Berdasarkan hasil kuesioner, acara rutin bersama selain olahraga tidak dilakukan, padahal acara rutin bersama ini sangat penting untuk membentuk kekompakkan tim. Namun demikian ada kegiatan rutin bersama dalam bentuk olahraga.

Frekuensi olahraga bersama dilakukan 1 kali dalam seminggu berdasarkan data kuesioner karyawan. Namun demikian supervisor tidak terlibat di dalam olahraga rutin bersama tersebut. Berdasarkan verifikasi, olahraga bersama ini ternyata inisiatif karyawan dan ini bisa dikembangkan untuk olahraga bersama pimpinan dan karyawan. Kekompakkan tim baik karyawan dan supervisor dapat terbentuk dari kegiatan olahraga bersama.

Efektivitas dan efisiensi SDM dapat ditingkatkan dari aktivitas yang sederhana seperti olahraga bersama atau kegiatan rutin lainnya seperti makan bersama, outing, kegiatan keagamaan dan sebagainya.

Berdasarkan data kuesioner, program K3 telah dilakukan di KHCR meliputi : pelatihan penggunaaan Alat Pemadam Api Ringan (APAR) dan Pertolongan Pertama pada Kecelakaan (P3K). Dua program tersebut memang sangat cocok untuk rumah makan karena penggunaan api pada kompor atau pemanas selain besarnya kemungkinan terjadi kecelakaan baik pada pekerja maupun tamu. Pelatihan pemadaman kebakaran dilakukan 1 bulan sekali, sedangkan P3K dilakukan 1 tahun sekali.

Program K3 sangat penting untuk meningkatkan efektivitas dan efisiensi 
SDM. Karyawan yang trampil akan bekerja dengan efektif untuk mengatasi musibah pada saat dini termasuk pada pertolongan pertama pada kecelakaan. Bagi perusahaan akan sangat meningkatkan efisiensi jika penanganan musibah dan kecelakaan bisa dilakukan pada saat awal.

Karyawan yang termotivasi akan bekerja dengan lebih baik, lebih efektif dan lebih efisien. Dalam penelitian ini, data tentang semangat karyawan digali dari kuesioner tentang pertanyaan "Apakah Saudara(i) merasa yakin akan dapat berperan dalam peningkatan produksi perusahaan?". Jawaban sebagian besar karyawan meyakini akan dapat berperan dalam peningkatan produksi perusahaan $(91,7 \%)$ hanya $8,3 \%$ yang tidak terlalu yakin terhadap kemampuannya untuk dapat berperan dalam peningkatan produksi perusahaan. Seluruh supervisor $(100 \%)$ meyakini dapat berperan dalam peningkatan produksi perusahaan. Cara untuk meningkatkan produksi perusahaan, jawaban yang diberikan dari kuesioner adalah : (1) bekerja dengan sesuai SOP (2) meningkatkan kinerja (3) membuat sistem kerja produksi yang lebih baik, dan (4) meningkatkan produksi.

Terhadap pertanyaan "Apakah Saudara(i) merasa yakin dapat meningkatkan mutu produk perusahaan?", seluruh karyawan dan supervisor meyakini dapat meningkatkan mutu produk perusahaan. Cara peningkatan mutu produksi perusahaan dari hasil kuesioner adalah : (1) meningkatkan ketelitian pekerjaan (2) mengikuti SOP (3) fokus dalam pekerjaan dan produk yang dihasilkan (4) membuat ragam produk baru (5) membuat Sertifikat Halal (6) membuat Sertifikat Layak Sehat, dan (7) membuat Sertifikat Pangan Industri Rumah Tangga (PIRT).

Efektivitas dan efisiensi SDM sangat ditentukan oleh semangat dan keyakinan karyawan untuk bekerja lebih baik yang dicerminkan dari jawaban kuesioner. Ketika ada karyawan $(8,3 \%)$ yang tidak terlalu yakin untuk meningkatkan produksi perusahaan, maka tugas manajemen memberikan pemahaman, semangat, dan pembinaan kepada karyawan tersebut.

Berdasarkan jawaban kuesioner ditemukan ada pesaing produk sejenis KHCR di Kota Bogor. Namun demikian seluruh karyawan dan supervisor meyakini bahwa produk KHCR lebih unggul dari pesaing produk sejenis dengan rata - rata skor 4,5 dari skor 1 sampai 5 (1: sangat di bawah produk saingan, 5: sangat unggul di atas produk saingan). Upaya yang dilakukan agar tetap unggul dari produk pesaing sejenis, berdasarkan jawaban kuesioner adalah :

a. Meningkatkan motivasi karyawan

b. Meningkatkan branding produk perusahaan

c. Aktif dalam komunitas bisnis

d. Mengenalkan kelebihan produk Klappertaart

e. Memperbaiki kekurangan suatu produk

f. Meningkatkan kualitas suatu produk, dan

g. Melakukan inovasi pada produk yang sudah ada.

Tantangan dari pesaing ternyata dapat meningkatkan motivasi karyawan terbukti dari optimisme yang disampaikan oleh karyawan dan supervisor. Motivasi tersebut pada saat yang sama sangat penting dalam meningkatkan efektivitas dan efisiensi di KHCR.

Terhadap pertanyaan "Bagaimana tingkat kepuasan terhadap pekerjaan yang saat ini dikerjakan?" sebagian besar karyawan menjawab puas hingga sangat puas, masing masing 50\% (skala kepuasan 8) dan 16,7\% (skala kepuasan 9). Sebesar $25 \%$ menjawab pada skala 7 (agak puas). Hanya $8,3 \%$ menjawab agak tidak puas seperti yang terlihat pada gambar 3.2. 


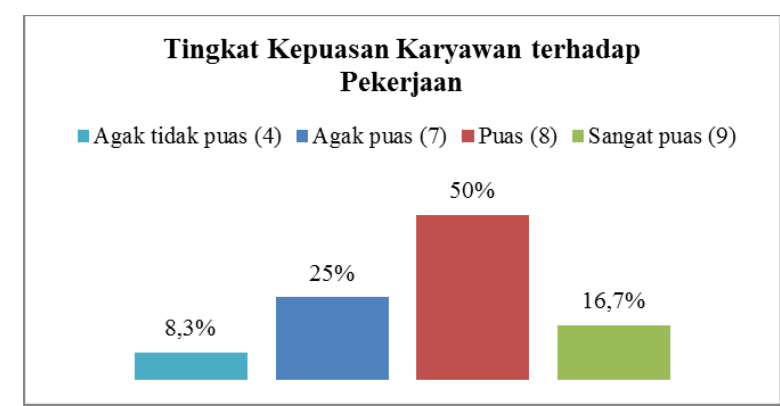

Sumber: Data diolah penulis, 2018

Gambar 3. Tingkat Kepuasan Karyawan terhadap Pekerjaan

Tingkat kepuasan yang cukup tinggi tersebut merupakan faktor penting dalam meningkatkan efektivitas dan efisiensi SDM di KHCR.

Upaya untuk meningkatkan efektivitas dan efisiensi pengelolaan SDM di KHCR juga ditentukan oleh pimpinan perusahaan. Pimpinan perusahaan yang dimaksud dalam penelitian ini adalah supervisor yang berperan dalam (1) upaya penghematan sumber daya, (2) mekanisme pengelolaan SDM, dan (3) motivasi, harapan, dan tantangan pimpinan perusahaan.

Terhadap pertanyaan "Dengan SDM dan modal produksi saat ini, apakah masih bisa melakukan penghematan sumberdaya lain?", seluruh supervisor meyakini bahwa masih bisa dilakukan upaya - upaya untuk menghemat sumber daya. Penghematan yang dilakukan adalah : (1) menambah peralatan kerja agar hemat bahan baku di perusahaan (2) membuat sistem kerja yang terencana (3) menggunakan bahan baku secara efisien (4) Menekan biaya cost gaji, dan (5) mengurangi limbah pangan.

Efektivitas dan efisiensi SDM ternyata masih memungkinkan, namun sebaiknya biaya gaji tidak ditekan agar kepuasan karyawan yang selama ini telah tinggi dapat dipertahankan.

Mekanisme pengelolaan SDM sangat menentukan efektivitas dan efisiensi SDM. Salah satu mekanisme pengelolaan SDM yang digali informasinya dari kuesioner adalah kepatuhan SDM untuk mengikuti Standard Operating Procedure (SOP).
SOP telah tersedia di Klappertaart dan secara terus-menerus diperbaharui sesuai dengan kebutuhan produksi. Menurut karyawan, SOP yang tersedia telah memadai dan memuaskan $(4,3)$ pada skala 1 sampai 5 . Namun demikian menurut pimpinan, kepatuhan karyawan terhadap penerapan SOP hanya 3,5 pada skala 1 sampai 5 .

Upaya untuk meningkatkan kepatuhan terhadap pelaksanaan SOP hendaknya terus- menerus ditingkatkan agar efektivitas dan efisiensi SDM di KHCR semakin baik.

Berdasarkan kuesioner terhadap supervisor, motivasi dan harapan pimpinan sangat tinggi termasuk menghadapi persaingan produk sejenis dari perusahaan lain. Hal ini terbukti dari:

a. Optimisme mengembangkan perusahaan $100 \%$,

b. Optimisme meningkatkan mutu produk $100 \%$,

c. Semangat menghadapi persaingan $100 \%$, dan

d. Kemungkinan melakukan penghematan sumber daya $100 \%$.

\section{Kesimpulan}

Efektivitas dan efisiensi manajemen SDM di KHCR dapat ditingkatkan misalnya dengan memperbanyak ragam media pengumuman penerimaan pegawai. Masa orientasi dan pelatihan ketrampilan karyawan termsuk faktor yang mempengaruhi efektivitas dan efisiensi SDM.

Penerapan reward dan punishment, pembinaan karyawan dengan kegiatan rutin bersama, peningkatan ragam program $\mathrm{K} 3$, dan semangat dan motivasi karyawan, sangat menentukan efektivitas dan efisiensi SDM.

Kepatuhan terhadap SOP, kemampuan pimpinan untuk mencari opsi penghematan, dan semangat karyawan menghadapi tantangan kompetitor sangat menentukan efektivitas dan efisiensi SDM. 


\section{Daftar Pustaka}

Badan Pusat Statistik Kota Bogor. 2017. Tabel Perkembangan wisatawan ke Kota Bogor. [Internet]. Tersedia dari : http://www.bps.go.id/linkTableDinam is/v iew/id/1116

Harianja, M.T.E. 2002. Manajemen Sumber Daya Manusia. Pt. Gramedia Widiasarana Indonesia, Jakarta.

Hasibuan JSB. 2014. Pembentukan Brand Awareness Melalui Media Sosial (Akun Facebook Dan Twitter) Lapis Bogor Sangkuriang. Jakarta (ID): Universitas Marcubuana.

Iswanto, Yun. 2014. Manajemen Sumber Daya Manusia dalam konsep dasar Manajemen Sumber Daya Manusia. Jakarta (ID) : Universitas Terbuka.

Priyana, I. 2016. Kajian Pemberdayaan Sumber Daya Manusia Dalam Upaya Mengoptimalkan Potensi Human Capital Perusahaan (Studi Kasus pada PT SIMNU di Bandung). Bandung (ID) :Universitas Pasundan. 